\author{
Abstracta Iranica \\ Abstracta Iranica Revue bibliographique pour le domaine irano-aryen \\ Volume 37-38-39 | 2018 \\ Comptes rendus des publications de 2014-2016
}

\title{
Matthew P. Canepa. "Dynastic Sanctuaries and the Transformation of Iranian Kingship between Alexander and Islam"
}

Luca Colliva

\section{(2) OpenEdition \\ Journals}

Electronic version

URL: http://journals.openedition.org/abstractairanica/44081

DOI: 10.4000/abstractairanica.44081

ISBN: 1961-960X

ISSN: 1961-960X

Publisher:

CNRS (UMR 7528 Mondes iraniens et indiens), Éditions de l'IFRI

\section{Electronic reference}

Luca Colliva, "Matthew P. Canepa. "Dynastic Sanctuaries and the Transformation of Iranian Kingship between Alexander and Islam" ", Abstracta Iranica [Online], Volume 37-38-39 | 2018, document 3, Online since 30 December 2018, connection on 28 September 2020. URL : http://journals.openedition.org/ abstractairanica/44081; DOI : https://doi.org/10.4000/abstractairanica.44081

This text was automatically generated on 28 September 2020

Tous droits réservés 


\title{
Matthew P. Canepa. "Dynastic Sanctuaries and the Transformation of Iranian Kingship between Alexander and Islam"
}

\author{
Luca Colliva
}

\section{REFERENCES}

Matthew P. Canepa. "Dynastic Sanctuaries and the Transformation of Iranian Kingship between Alexander and Islam" in S. Babaie \& T. Grigor (eds.). Persian Kingship and Architecture, Strategies of Power in Iran from the Achaemenids to the Pahlavis. London-New York I.B. Tauris, 2015, 65-117.

1 The interpretation of the so-called Dynastic Sanctuaries created by "Iranian-speaking" or "Iranian-influenced" dynasties between the Hellenistic period and the Islamic conquest is a long debated subject. In this article M.P. Canepa takes into consideration some possible sanctuaries, located in a vast area stretching from Commagene to Kushan India. The examined sites, which include Nemrut Daği, Old Nisa, Šāmī, Surkh Kotal, Māt and Naqš-e Rostam, are emblematic for their links with the ruling dynasties. According to the author, they were erected to honour the sovereign, his relatives and ancestors, and render cult to the gods, sometimes also in conjunction with funerary monuments, thus establishing a clear connection between the king and the divine.

2 The study of these sites and the comparison with the Hellenistic tradition, mainly vehiculated by Seleucids, suggest to the author that the origin of these sanctuaries can be traced to the birth of a new pan-Iranian conception of kingship forged by the union of Hellenistic and Iranian traditions. 


\section{AUTHORS}

LUCA COLLIVA

Adjunct Professor at School of Arts, Humanities and Cultural Heritage, "Alma Mater Studiorum" University of Bologna 